\title{
Hyperthermostable Thermotoga maritima xylanase XYN10B shows high activity at high temperatures in the presence of biomass-dissolving hydrophilic ionic liquids
}

\author{
Tianyi $\mathrm{Yu}^{1} \cdot$ Sasikala Anbarasan $^{2} \cdot$ Yawei Wang $^{1} \cdot \mathrm{Kübra} \mathrm{Telli}^{2} \cdot$ Aşkın Sevinç Aslan $^{2}$ • \\ Zhengding $\mathrm{Su}^{3} \cdot$ Yin $\mathrm{Zhou}^{4} \cdot \mathrm{Li}^{\mathrm{Zhang}}{ }^{1} \cdot \mathrm{Piia}_{\text {Iivonen }}{ }^{2} \cdot$ Sami Havukainen $^{2}$ • \\ Tero Mentunen ${ }^{2} \cdot$ Michael Hummel $^{5} \cdot$ Herbert Sixta $^{5} \cdot$ Baris Binay $^{6} \cdot$ Ossi Turunen $^{2}$. \\ Hairong Xiong ${ }^{1}$
}

Received: 29 January 2016 / Accepted: 15 May 2016 / Published online: 30 May 2016

(C) The Author(s) 2016. This article is published with open access at Springerlink.com

\begin{abstract}
The gene of Thermotoga maritima GH10 xylanase (TmXYN10B) was synthesised to study the extreme limits of this hyperthermostable enzyme at high temperatures in the presence of biomass-dissolving hydrophilic ionic liquids (ILs). TmXYN10B expressed from Pichia pastoris showed maximal activity at $100{ }^{\circ} \mathrm{C}$ and retained $92 \%$ of maximal activity at $105{ }^{\circ} \mathrm{C}$ in a 30 -min assay. Although the temperature optimum of activity was lowered by 1-ethyl-3-methylimidazolium acetate ([EMIM] OAc), TmXYN10B retained partial activity in 15-35\% hydrophilic ILs, even at $75-90{ }^{\circ} \mathrm{C}$. TmXYN10B retained
\end{abstract}

Communicated by H. Atomi.

T. Yu and S. Anbarasan contributed equally to the study.

Electronic supplementary material The online version of this article (doi:10.1007/s00792-016-0841-y) contains supplementary material, which is available to authorized users.

Ossi Turunen

ossi.turunen@aalto.fi

$\triangle$ Hairong Xiong

xionghr@mail.scuec.edu.cn

1 South-Central University for Nationalities, College of Life Science, Wuhan 430074, China

2 Department of Biotechnology and Chemical Technology, School of Chemical Technology, Aalto University, 00076 Aalto, Finland

3 Hubei University of Technology, Wuhan 430068, China

4 Wuhan Sunhy Biology Co., Ltd, Wuhan 430074, China

5 Department of Forest Products Technology, School of Chemical Technology, Aalto University, 00076 Aalto, Finland

6 Department of Bioengineering, Gebze Technical University, 41400 Gebze Kocaeli, Turkey over $80 \%$ of its activity at $90{ }^{\circ} \mathrm{C}$ in $15 \%$ [EMIM]OAc and 15-25\% 1-ethyl-3-methylimidazolium dimethylphosphate ([EMIM]DMP) during 22-h reactions. [EMIM]OAc may rigidify the enzyme and lower $V_{\max }$. However, only minor changes in kinetic parameter $K_{\mathrm{m}}$ showed that competitive inhibition by [EMIM]OAc of TmXYN10B is minimal. In conclusion, when extended enzymatic reactions under extreme conditions are required, TmXYN10B shows extraordinary potential.

Keywords GH10 xylanase - Thermotoga maritima . Extreme stability · Ionic liquids · Competitive inhibition . Expression in Pichia pastoris

\section{Introduction}

Xylanases, members of glycosidases (O-glycoside hydrolases, EC 3.2.1.x), catalyse the endohydrolysis of 1,4-betaD-xylosidic linkages in xylan (Collins et al. 2005). Thermostable xylanases are widely used in biotechnological processes that take place at high temperatures, such as those in the feed and pulp and paper industry (Vieille and Zeikus 2001; Kumar et al. 2016). Xylanases are also used in industrial applications for the deconstruction of plant cell walls to facilitate biofuel production from lignocellulose. Lignocellulosic materials from agricultural and forestry waste can serve as key substrates for second-generation biofuels due to their low cost and abundance (Yeoman et al. 2010; Bhalla et al. 2013). Xylanases are used in the decomposition of the hemicellulosic components of the biomass.

The application of thermostable enzymes in industrial processes, which are carried out at high temperatures, have several advantages, including extended reaction times and also stability against denaturing conditions other than 
heat (Yeoman et al. 2010). Elevated temperatures lead to faster reactions, higher mass transfer rates, lower viscosity, increased solubility of reactants and products, lowered risk of contamination from mesophilic microbes and therefore improved hydrolysis performance. A temperature of $100{ }^{\circ} \mathrm{C}$ offers advantages for the enzymatic treatment of lignocellulose (Hämäläinen et al. 2015). Enzyme activity at these temperatures requires extreme stability and preferably a long half-life of the enzyme. Highly thermostable xylanases from diverse thermophilic microbes have been described (Canakci et al. 2012; Shrivastava et al. 2013). Synergy effects between different enzymes are important in lignocellulose hydrolysis (Hämäläinen et al. 2015; Malgas et al. 2015).

Different mutagenesis methods have been adopted to improve the thermostability of xylanases, and these have led to significant improvements in the thermostability (Palackal et al. 2004; Xiong et al. 2004; Dumon et al. 2008; Wang et al. 2012; Li et al. 2013; Song et al. 2015). Even xylanases with low native thermostability can be engineered to have remarkably high stability levels (Jänis et al. 2001, 2004; Palackal et al. 2004; Xiong et al. 2004). Although the optimum temperature for the activity of Dictyoglomus thermophilum GH11 xylanase is around $85-90{ }^{\circ} \mathrm{C}$, a mutant was generated with a slightly higher (about $5{ }^{\circ} \mathrm{C}$ ) temperature optimum ( $\mathrm{Li}$ et al. 2013), showing that protein engineering can improve the thermostability of hyperthermostable enzymes. With regard to hyperthermostable xylanases, those found in natural microbes still have the highest level of thermostability. The temperature optimum of Thermotoga maritima GH10 xylanase was $105{ }^{\circ} \mathrm{C}$ in a 5-min assay (Winterhalter and Liebl 1995; Reeves et al. 2000; Ihsanawati et al. 2005) and that of Pyrodictium abyssi GH10 xylanase was $110^{\circ} \mathrm{C}$ (Andrade et al. 2001).

Hydrophilic ionic liquids (ILs) have been used successfully as dissolving agents in the pretreatment of lignocellulose for improved enzyme hydrolysis (Wahlström and Suurnäkki 2015). [EMIM]OAc is a common IL used in lignocellulose-dissolving experiments. These biomass-dissolving ILs are usually harmful to an enzyme, causing both unfolding of the structure and competitive inhibition of the enzyme activity (Vancov et al. 2012; Jaeger and Pfaendtner 2013; Li et al. 2013; Chawachart et al. 2014). The competitive inhibition of enzyme activity and the disruption of enzyme structure by [EMIM]-based ionic liquids has been observed also in molecular dynamics simulations (Jaeger and Pfaendtner 2013; Jaeger et al. 2015). Finding or engineering enzymes compatible with biomass-dissolving ILs would make it possible to study the activity of enzymes in lignocellulose hydrolysis or modification, together with high concentrations of biomass-dissolving ILs. In addition, high temperature and biomass-dissolving ILs form a model for extreme conditions to study the enzyme behaviour. In the present study, the T. maritima GH10 xylanase (TmXYN10B) was expressed in Escherichia coli and Pichia pastoris. The effect of the expression system on its enzymatic properties and the limits of T. maritima GH10 xylanase at high temperatures in the presence of biomass-dissolving ILs were then investigated.

\section{Materials and methods}

\section{Strains, vectors and materials}

Escherichia coli BL21 (DE3) (Transgen, China) was used as the host for prokaryotic protein expression. It was grown aerobically in Luria-Bertani broth with $100 \mu \mathrm{g}$ of ampicil$\mathrm{lin} / \mathrm{mL}$. The vector $\mathrm{pET}-22 \mathrm{~b}(+)$ and shuttle vector pPIC9 (Invitrogen, China) were used for secretion of target proteins. All enzymes were purchased from Takara (Japan). Primers and genes were synthesised by Tsingke Biotech (China). P. pastoris GS115 (Invitrogen, Beijing, China) was used as the host for eukaryotic protein expression. The culture media were: minimal dextrose (MD), yeast extract peptone dextrose (YPD), buffered glycerol-complex (BMGY) and buffered methanol-complex (BMMY). All chemical reagents were of analytical pure grade.

\section{Construction of the recombinant plasmid}

According to the reported complete genome of T. maritima MSB8 [NCBI (The National Center for Biotechnology Information) database reference sequence: NC_023151, 1,869,644 bp], the xylanase 10B gene in the $873531 \ldots 874574$ (Gene ID: 18092741, 1044 bp) region was selected to construct the TmXYN10B gene. The synthesised sequence was deposited in NCBI database (Gene ID: KR078269, 984 bp; protein ID: AKT33673, 328 amino acids). The TmXYN10B sequence was designed to avoid the $E c o R$ I and $B g l$ II recognition sites in the construction of GS115-Xyn10B plasmid for expression in P. pastoris. The xylanase TmXYN10B sequence was optimised by removing rare codons and optimising the codon usage for expression in $P$. pastoris. The full-length xylanase gene TmXYN10B was synthesised by Tsingke Biotech. The mature gene was inserted into endonuclease sites of Xho I and Nco I in plasmid pET-22b(+). While the gene was inserted in pET$22 \mathrm{~b}(+)$, the termination codon was removed to link the Histag with the C-terminal of the TmXYN10B protein. Meanwhile, the full-length gene was inserted into the restriction endonucleases sites of EcoR I and Not I. The secretion signal sequence was from the expression vector. The two recombinant plasmids were preserved in E. coli $\mathrm{DH} 5 \alpha$.

\section{Expression of xylanase in $E$. coli and $P$. pastoris}

The expression plasmid pET-22b(+)-Xyn10B was transformed into competent $E$. coli BL21 (DE3) cells. The cells 
were cultivated at $37{ }^{\circ} \mathrm{C}$ for $12 \mathrm{~h}$. The protein expression was then induced by isopropyl- $\beta$-D-thiogalactopyranoside (IPTG) at a final concentration of $0.5 \mathrm{mM}$ and incubated at $28{ }^{\circ} \mathrm{C}$ for $16 \mathrm{~h}$. The pPIC9-Xyn $10 B$ plasmid was digested with $B g l$ II and then transformed into competent $P$. pastoris GS115 cells by electroporation. Transformants were screened on MD plates lacking histidine. Positive colonies were transferred into $5 \mathrm{~mL}$ of BMGY medium and grown at $30{ }^{\circ} \mathrm{C}$ for 2 days. The cells were pelleted by centrifugation and resuspended in $1 \mathrm{~mL}$ of BMMY containing $0.5 \%$ methanol for $72 \mathrm{~h}$ to induce protein expression. Batch cultivation was carried out in a 20-L bioreactor (Sartorius, Germany) to grow the GS115-Xyn10B for producing the TmXYN10B protein. The cultivation parameters were as follows: agitation at $200 \mathrm{rpm}$ (tip speed $0.6 \mathrm{~m} / \mathrm{s}$, two Rushton type impellers), aeration of $0.3 \mathrm{vvm}$ (volume air per volume liquid per minute) and cultivation for 8 days at $28{ }^{\circ} \mathrm{C}$ (Xiong et al. 2009).

\section{Purification of the TmXYN10B protein}

The culture supernatant of E.coli pET-22b-Xyn10B was collected by centrifugation at $4{ }^{\circ} \mathrm{C}$ and $10,000 \times g$ for $15 \mathrm{~min}$. The cell-free supernatant was filtered with a $10-\mathrm{kDa}$ membrane. The filtered supernatant was loaded to a $1 \mathrm{~mL}$ immobilised $\mathrm{Ni}^{2+}$ affinity column (Novagen, Wisconsin) and eluted with elution buffer (0.4 M imidazole, $0.5 \mathrm{M} \mathrm{NaCl}$, and $20 \mathrm{mM}$ Tris- $\mathrm{HCl}, \mathrm{pH}$ 7.9). The eluent was concentrated and analysed by sodium dodecyl sulphate polyacrylamide gel electrophoresis (12 \% SDS-PAGE). The protein concentrations were determined by the Bradford method, using bovine serum albumin (BSA) (SigmaAldrich, MO, USA) as the standard.

The culture supernatant of $P$. pastoris GS115 was collected by centrifugation for $15 \mathrm{~min}$ at $10,000 \times g, 4{ }^{\circ} \mathrm{C}$. The cell-free supernatant was precipitated with ammonium sulphate $(80 \%$ saturation). After centrifugation $\left(5000 \times g\right.$ for $\left.30 \mathrm{~min}, 4^{\circ} \mathrm{C}\right)$, the pellet was dissolved in $25 \%$ saturated ammonium sulphate in $20 \mathrm{mM}$ phosphate buffer ( $\mathrm{pH}$ 6.0). The P. pastoris-expressed enzyme $(\sim 5 \mu \mathrm{g})$ was deglycosylated by $3000 \mathrm{U}$ of endo- $\beta-\mathrm{N}$ acetylglucosaminidase $\mathrm{H}$ (Endo $\mathrm{H}$ ) at $37{ }^{\circ} \mathrm{C}$ for $2 \mathrm{~h}$, according to the manufacturer's instructions (New England Biolabs, MA, USA). The deglycosylated and untreated enzymes were analysed by SDS-PAGE. According to manufacturer, the apparent molecular weight of endo $\mathrm{H}$ is $29 \mathrm{kDa}$. The molecular weight marker was PageRuler Prestained Protein Ladder, 10-180 kDa (ThermoFisher, Scientific, MA, USA).

\section{Enzyme activity assays}

The enzymatic activities of the produced xylanases were determined by reaction in a $1 \mathrm{~mL}$ mixture containing $100 \mu \mathrm{L}$ of appropriately diluted enzymes and $900 \mu \mathrm{L} 0.5 \%$ (w/v) beechwood xylan (X4252, Sigma-Aldrich, MO, USA), which was dissolved in $50 \mathrm{mM}$ phosphate buffer, pH 6.0. The DNS method with a 10-min assay length was used for determination of the enzyme activity (Xiong et al. 2004). Enzyme assays (10 min) were also performed with up to $2.0 \mathrm{M}$ sodium chloride at $90{ }^{\circ} \mathrm{C}, \mathrm{pH}$ 5. The specific activity of TmXYN10B was measured at $90{ }^{\circ} \mathrm{C}$ and $\mathrm{pH}$ 5. One unit (IU) of enzyme activity was defined as the amount of enzyme releasing 1 micromole of reducing sugars per min. The half-life was determined by incubating the enzyme samples at $100{ }^{\circ} \mathrm{C}(\mathrm{pH} 5$, initially at room temperature) for various time intervals. Thereafter, the remaining activity was measured at $90^{\circ} \mathrm{C}, \mathrm{pH}$, with a 10 -min assay. All these experiments were done with the enzymes purified as described above unless otherwise stated. In the assays, $0.1 \mathrm{mg} / \mathrm{mL}$ of BSA was used as a stabiliser.

\section{Enzyme activity in the presence of ILs}

The effect of 1-ethyl-3-methylimidazolium acetate ([EMIM]OAc) (BASF, Germany), with a purity of $\geq 95 \%$, 1-ethyl-3-methylimidazolium dimethylphosphate ([EMIM] DMP) (IoLiTec, Germany), with a purity of $\geq 98 \%$, and 1,5-diazabicyclo[4.3.0]non-5-enium acetate ([DBNH]OAc) on the temperature-dependent activity of TmXYN10B was investigated with the enzyme expressed in $P$. pastoris. [DBNH]OAc was prepared by slowly adding equimolar amounts of acetic acid (glacial, $100 \%$, Merck, Germany) to 1,5-Diazabicyclo[4.3.0]non-5-ene (99\%, Fluorochem, UK), while diverting the enthalpy of the exothermic reaction by active cooling. The IL experiments were done with the non-purified supernatant enzyme (precipitates were removed) produced from Pichia. The amount of total supernatant protein including the enzyme in one experiment was below $0.1 \mathrm{mg} / \mathrm{mL}$. $0.1 \mathrm{mg} / \mathrm{mL}$ of BSA was used as a stabiliser. The experiments were done at pH 7 in $50 \mathrm{mM}$ citrate-phosphate buffer using $1 \%$ birchwood xylan (Sisco Research Laboratories, India) as a substrate. The activity at $105{ }^{\circ} \mathrm{C}$ was measured in closed tubes incubated in a silicon oil bath. The time-dependent activity of TmXYN10B with [EMIM]OAc was measured at 75 and $90^{\circ} \mathrm{C}, \mathrm{pH}$ 7. A pH of 7 was used to avoid precipitation, which easily occurs at a lower $\mathrm{pH}$. The reaction products were measured by a DNS assay. The $\mathrm{pH}$ was adjusted each time after the addition of the IL to the reaction solution. Xylose standards with IL were used to determine the amount of the produced sugars in the presence of ILs.

The kinetic parameters with and without [EMIM]OAc were determined by a DNS assay, with 30-min incubations at $\mathrm{pH} 7$ and using $1 \%$ birchwood xylan as the substrate. The kinetic parameters were calculated by hyperbolic regression analysis in Hyper32 software (http://homepage. ntlworld.com/john.easterby/software.html). The relative 
$V_{\max }$ was calculated to illustrate the effect of [EMIM]OAc on the kinetics values.

\section{Molecular docking by SwissDock}

Molecular docking of $[\mathrm{EMIM}]^{+}$and $[\mathrm{DBNH}]^{+}$cations by SwissDock (http://www.swissdock.ch/) to the TmXYN10B structure (PDB code 1VBR) was done in the same way as described earlier for T. aurantiacus GH10 xylanase (Chawachart et al. 2014). The cation structures were energy minimised by MM2 in ChemBio3D Ultra 12.0 (CambridgeSoft, UK) for docking experiments. The accurate mode option of SwissDock was used, and flexibility was allowed for the ligand.

\section{Results}

\section{Cloning and expression of the TmXYN10B gene}

The xylanase TmXYN10B sequence was obtained from the complete genome of T. maritima MSB8. The protein structure is known (PDB code 1VBR, 324 amino acids). After optimising the codon usage of the gene, the synthesised TmXYN10B gene (GenBank: KR078269) was constructed and expressed in E. coli and P. pastoris. The prokaryotic expression of TmXYN10B was induced by IPTG in E. coli BL21 (DE3) under the control of the $\mathrm{T} 7$ promoter, and the eukaryotic expression was induced by methanol in $P$. pastoris GS115 under the control of the AOX promoter. The TmXYN10B proteins were produced in the culture medium, from which they were purified and identified in SDS-PAGE. Protein sizes close to $40 \mathrm{kDa}$, consistent with the predicted size, were produced in E. coli and P. pastoris (Fig. 1). The protein produced in $E$. coli had a size of $38 \mathrm{kDa}$, and the protein produced in $P$. pastoris had a size of $42 \mathrm{kDa}$, indicating that $\mathrm{TmXYN} 10 \mathrm{~B}$ produced in $P$. pastoris was glycosylated. After treatment with Endo $\mathrm{H}$ specific for $\mathrm{N}$-glycosylation, a second protein version appeared. This protein had an apparent molecular mass of $38 \mathrm{kDa}$, which was the same as that of the enzyme produced in E. coli (Fig. 1). The amino acid sequence of TmXYN10B contains several theoretical N-glycosylation sites (not shown).

\section{Enzymatic properties of TmXYN10B}

The enzyme inactivation of TmXYN10B expressed in E. coli and P. pastoris as a function of time was compared (Fig. 2; see also Supplemental Data Fig. S1). When

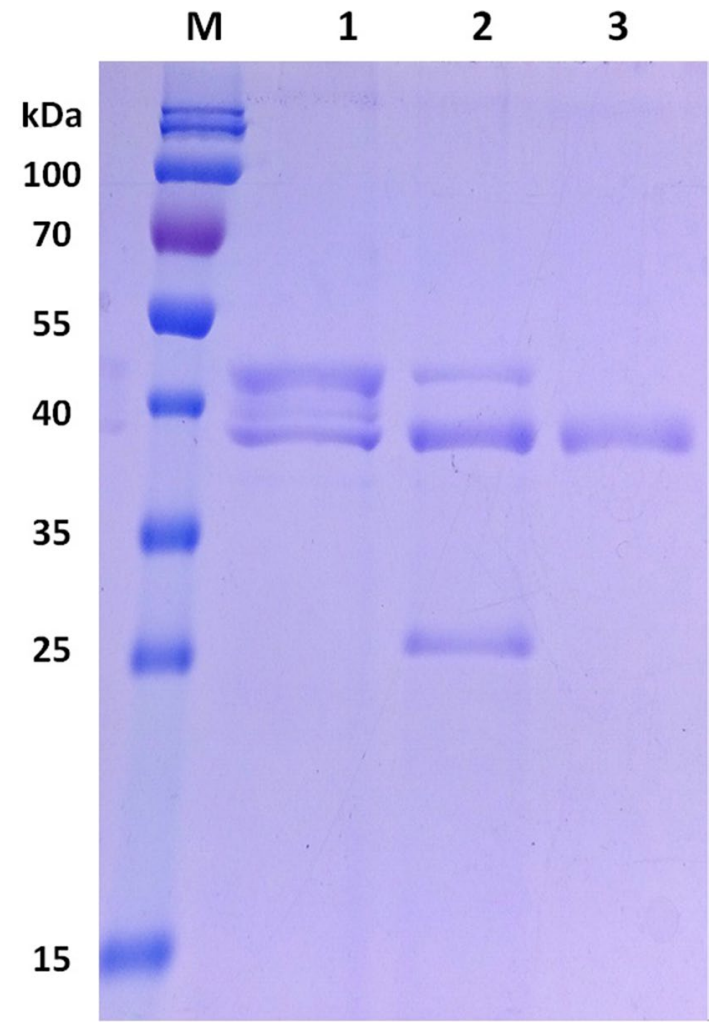

Fig. 1 SDS-PAGE analysis of TmXYN10B proteins. $M$ PageRuler Prestained Protein Ladder, $10-180 \mathrm{kDa} .1$ the recombinant TmXYN10B expressed in P. pastoris; 2 TmXYN10B after deglycosylation with endo $\mathrm{H}$ (the lower band is the $29 \mathrm{kDa}$ endo $\mathrm{H}$ ); 3 TmXYN10B expressed in E. coli. About $5 \mu \mathrm{g}$ of protein was loaded into each sample lane

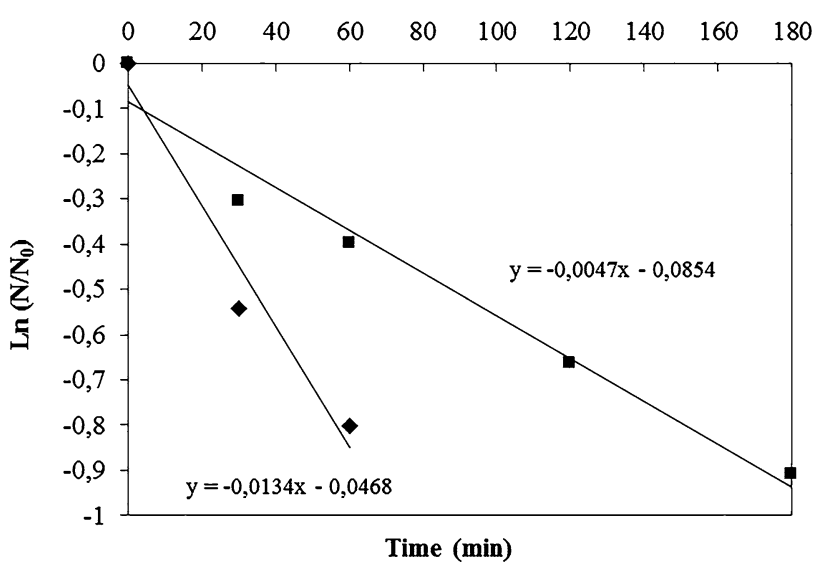

Fig. 2 Inactivation of TmXYN10B at $100{ }^{\circ} \mathrm{C}(\mathrm{pH}$ 5). E. coliexpressed TmXYN10B (filled rhombus) and P. pastoris-expressed TmXYN10B (filled square). In $Y$-axis, $N_{0}$ is the activity value at time point 0 and $N$ at each incubation time point. The figure shows the inactivation graph of $E$. coli-expressed enzyme for the initial 0-60 min (half-life $48 \mathrm{~min}$ ) and for 0-180 min (half-life $130 \mathrm{~min}$ ) in P. pastoris-expressed enzyme (see Fig. S1 in Supplemental Data) 


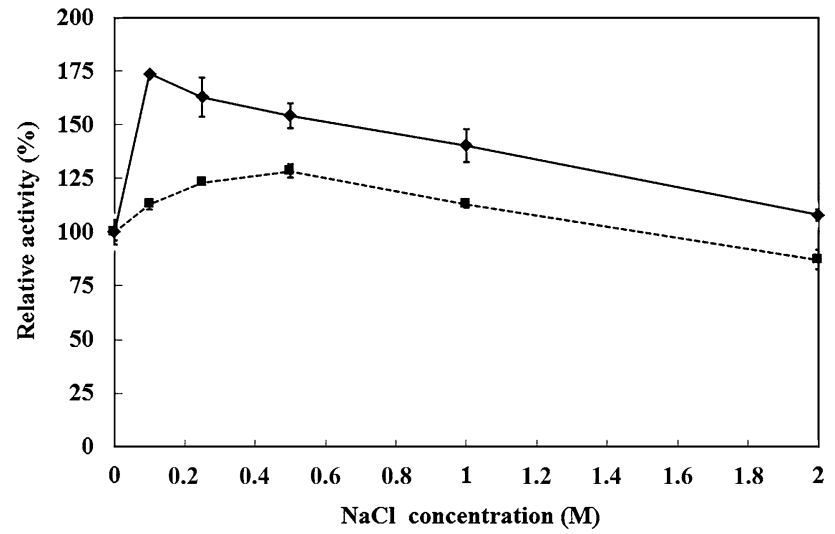

Fig. 3 Effect of $\mathrm{NaCl}$ concentration on the activity of TmXYN10B. The enzyme expressed in E. coli (filled rhombus) and P. pastoris (filled square). The enzyme reaction was done at $90{ }^{\circ} \mathrm{C}, \mathrm{pH} 5$, for $10 \mathrm{~min}$

incubated at $100{ }^{\circ} \mathrm{C}$ and $\mathrm{pH} 5$, the half-life times of $\mathrm{TmX}$ YN10B expressed in E. coli and P. pastoris were about 48 and $130 \mathrm{~min}$, respectively (Fig. 2 and Fig. S1 in Supplemental Data). Therefore, the thermostability assay showed that the enzyme produced in P. pastoris was more stable than the enzyme produced in E. coli. Although the underlying reason was not studied, it could be due to the difference in glycosylation (from Pichia) or His-tag (in E. coli expression). The enzyme produced in P. pastoris had a wider $\mathrm{pH}$ stability region on both the acidic and alkaline side (not shown). The results are in line with the earlier studies showing that the expression systems can have a significant effect on the activity and stability of enzymes (Anbarasan et al. 2010).

At $90{ }^{\circ} \mathrm{C}$ and $\mathrm{pH} 5$, the specific activity of TmXYN10B expressed in E. coli was $375 \mathrm{IU} / \mathrm{mg}$, whereas the specific activity of TmXYN10B expressed in P. pastoris was $110 \mathrm{IU} / \mathrm{mg}$. The lower activity of the enzyme expressed from Pichia may be caused by lower purity. However, given the lack of significant other impurities (Fig. 1), the lower bands in Pichia-expressed protein (Fig. 1, lane 1) likely represent a glycosylation variant and a non-glycosylated form. Glycosylation may also have decreased the specific activity.

The effect of sodium chloride on the activity of TmXYN10B produced in E.coli and P. pastoris is shown in Fig. 3. TmXYN10B was clearly activated by sodium chloride, as shown in earlier studies (Winterhalter and Liebl 1995). However, in the present study, the activation of the TmXYN10B enzyme in response to sodium chloride differed in E. coli and P. pastoris, with significantly higher activation when expressed in E. coli, with the C-terminal His-tag and without glycosylation. For

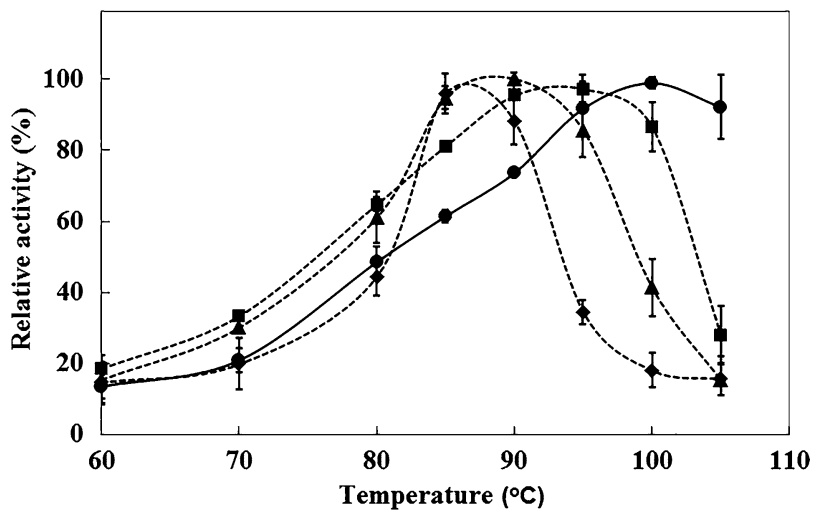

Fig. 4 Effect of [EMIM]OAc on temperature-dependent activity of P. pastoris-expressed TmXYN10B. The experiments were done at $\mathrm{pH}$ 7, with 30-min incubation. The maximal activity in each IL concentration was defined as $100 \%$. Symbols: without [EMIM]OAc (filled circle) and with $15 \%$ (filled square), $25 \%$ (filled triangle), and $35 \%$ (filled rhombus) [EMIM]OAc

both enzyme forms, the activity in $2 \mathrm{M} \mathrm{NaCl}$ was close to same.

\section{Thermal activity of TmXYN10B in the presence of ILs}

The ability of highly thermophilic enzymes to tolerate ILs was tested earlier. The results showed that [EMIM]OAc decreased significantly the apparent temperature optimum of $D$. thermophilum and $T$. aurantiacus xylanases and melting temperature $\left(T_{\mathrm{m}}\right)$ of $T$. aurantiacus xylanase $(\mathrm{Li}$ et al. 2013; Chawachart et al. 2014). TmXYN10B is more thermostable, with a higher temperature optimum $\left(10-25{ }^{\circ} \mathrm{C}\right.$ higher) than other xylanases studied earlier. The decreases in the temperature optimum of TmXYN10B were 5, 10 and $15{ }^{\circ} \mathrm{C}$, with 15,25 and $35 \%$ of [EMIM]OAc, respectively (Fig. 4). Thus, in 15-35\% aqueous solutions, the extremophilic TmXYN10B still behaved as a highly thermophilic enzyme.

With regards to the activity as a function of time, at $75{ }^{\circ} \mathrm{C}$, the enzyme remained active during incubation for $24 \mathrm{~h}$ in 15 and $25 \%$ [EMIM]OAc. Although the graphs bend, they still show that the enzyme was highly active during the whole time period. The ILs lowered the enzyme activity, but some activity remained even in $35 \%$ [EMIM] OAc (Fig. 5). High stability in ILs was seen even at $90{ }^{\circ} \mathrm{C}$, at which temperature we tested three ILs ([EMIM]OAc, [EMIM]DMP and [DBNH]OAc), and the results are shown for 30-min and 22-h incubations (Fig. 6a, b). All three ILs were tolerated quite well during incubation for $30 \mathrm{~min}$, TmXYN10B showing the highest activity in [EMIM]OAc (Fig. 6a). The reaction product accumulation at $90{ }^{\circ} \mathrm{C}$ during 


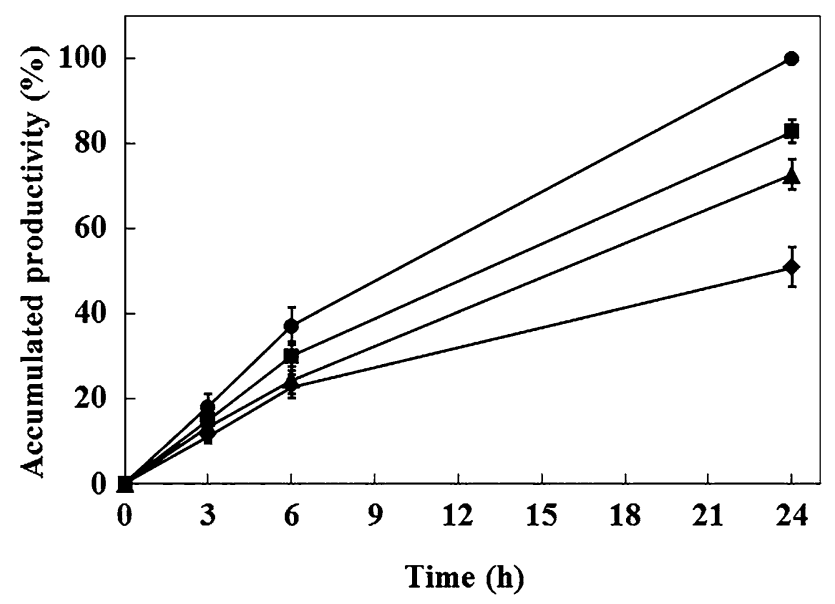

Fig. 5 Time-dependent activity of TmXYN10B with [EMIM]OAc. The reaction was performed with $1 \%$ birchwood xylan at $75^{\circ} \mathrm{C}, \mathrm{pH}$ 7. Symbols: without [EMIM]OAc (filled circle) and with $15 \%$ (filled square), $25 \%$ (filled triangle), and $35 \%$ (filled rhombus) [EMIM] OAc. Relative activity (\%) in the $X$-axis shows the relative production of the cleavage products from the same enzyme amount in the different assays
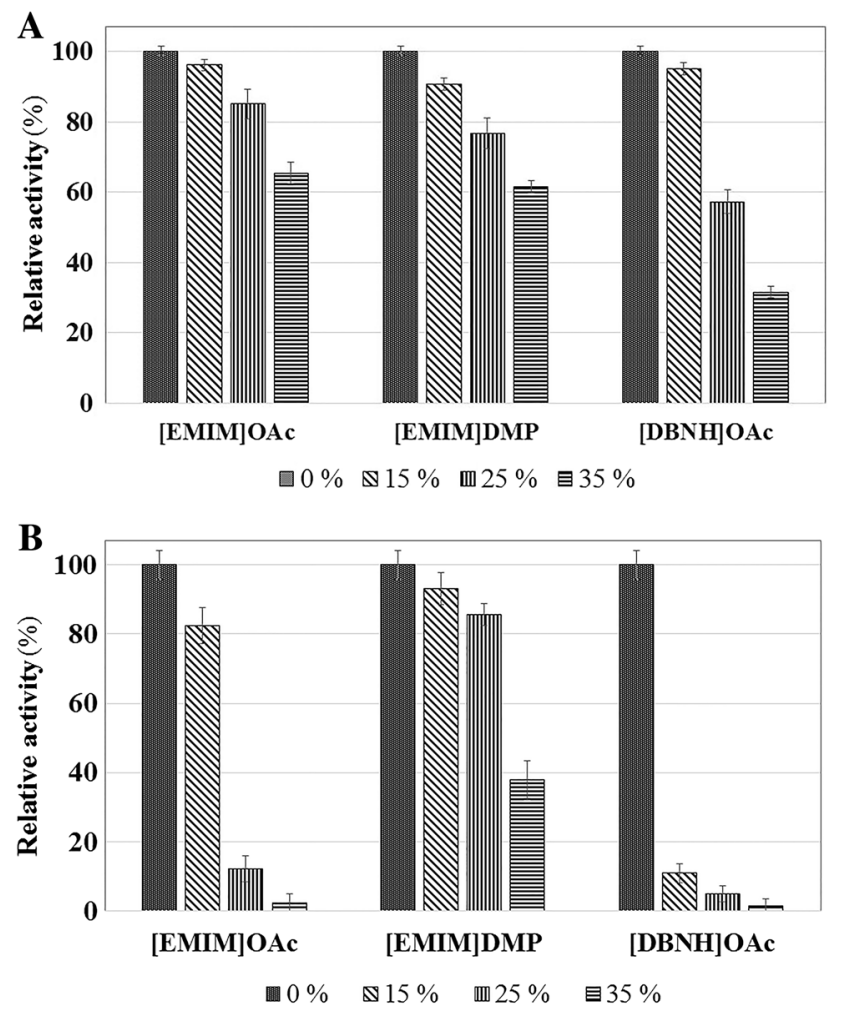

Fig. 6 Activity of TmXYN10B in ILs at $90{ }^{\circ} \mathrm{C}$. The reactions were performed at $\mathrm{pH} 7$ with $1 \%$ birchwood xylan in a 30-min and b 22-h incubations

$22 \mathrm{~h}$ showed close to the same level in $15 \%$ [EMIM]OAc and 15 and $25 \%$ [EMIM]DMP than without IL, whereas 25 and $35 \%$ [EMIM]OAc, $35 \%$ [EMIM]DMP and [DBNH]
OAc decreased remarkably the enzyme activity (Fig. 6b). Surprisingly, now [EMIM]DMP was much better tolerated than [EMIM]OAc or [DBNH]OAc (Fig. 6b). These results pointed to significant differences in the effects of closely related ILs on the activity and stability of hyperthermostable TmXYN10B under differing conditions.

The kinetic parameters showed that [EMIM]OAc decreased $V_{\max }$ and the catalytic performance $V_{\max } / K_{\mathrm{m}} \sim 1.6$ to 3.4-fold at $70-100{ }^{\circ} \mathrm{C}$ (Table 1; the corresponding graphs are shown in Supplemental Data Fig. S2). There was no dramatic increase in the kinetic parameter $K_{\mathrm{m}}$, reflecting substrate binding to enzyme, in response to [EMIM]OAc. In addition, the $K_{\mathrm{m}}$ increased only 1.8 -fold from 0.69 to $1.22 \mathrm{mg} / \mathrm{mL}$ when the temperature was increased from 70 to $100{ }^{\circ} \mathrm{C}$, indicating that the enzyme binds well to the substrate, even at $100{ }^{\circ} \mathrm{C}$.

\section{Molecular docking of IL cations to the enzyme active site}

The molecular docking by SwissDock with the $[\mathrm{EMIM}]^{+}$ and $[\mathrm{DBNH}]^{+}$cations was done in the same way as described earlier for $T$. aurantiacus GH10 xylanase (Chawachart et al. 2014). SwissDock grouped 256 docking poses to over 30 clusters. Ten clusters containing 80 poses were detected in the active site for $[\mathrm{EMIM}]^{+}$cations, and 17 clusters containing 104 poses were detected in the active site for $[\mathrm{DBNH}]^{+}$cations. Figure $7 \mathrm{a}$ and $\mathrm{b}$ show the first hits of every cluster bound to the active site. The highest binding energy for the $[\mathrm{DBNH}]^{+}$cations was $-6.54 \mathrm{kcal} /$ $\mathrm{mol}$, and it was $-6.77 \mathrm{kcal} / \mathrm{mol}$ for the $[\mathrm{EMIM}]^{+}$cations. The average binding energies ( \pm standard deviation) of all docking poses in the active site were $-6.18 \pm 0.29 \mathrm{kcal} /$ mol for the $[\mathrm{EMIM}]^{+}$cations and $-6.04 \pm 0.30 \mathrm{kcal} / \mathrm{mol}$ for the $[\mathrm{DBNH}]^{+}$cations. These differences in the binding energies are likely too small for having functional significance. The extent of the binding areas is probably more

Table 1 Kinetic parameters of TmXYN10B

\begin{tabular}{lcll}
\hline Without IL & $K_{\mathrm{m}}(\mathrm{mg} / \mathrm{mL})$ & Relative $V_{\max }$ & $V_{\max } / K_{\mathrm{m}}$ \\
\hline $70{ }^{\circ} \mathrm{C}$ & $0.69 \pm 0.06$ & $1.00 \pm 0.07$ & 1.4 \\
$90^{\circ} \mathrm{C}$ & $0.72 \pm 0.11$ & $2.47 \pm 0.03$ & 3.4 \\
$100^{\circ} \mathrm{C}$ & $1.22 \pm 0.17$ & $3.67 \pm 0.05$ & 3.0 \\
With $15 \%$ & & \\
$70^{\circ} \mathrm{C}$ & $0.51 \pm 0.04$ & $0.47 \pm 0.01$ & 0.9 \\
$90^{\circ} \mathrm{C}$ & $1.41 \pm 0.09$ & $1.34 \pm 0.01$ & 1.0 \\
$100^{\circ} \mathrm{C}$ & $1.39 \pm 0.20$ & $1.57 \pm 0.02$ & 1.1 \\
\hline
\end{tabular}

In relative $V_{\max }$, the value at $70{ }^{\circ} \mathrm{C}$ without [EMIM]OAc is defined as 1. The kinetic values are for the same amounts of enzyme. As TmXYN10B expressed in $P$. pastoris was not purified, only the relative $V_{\max }$ is reported 

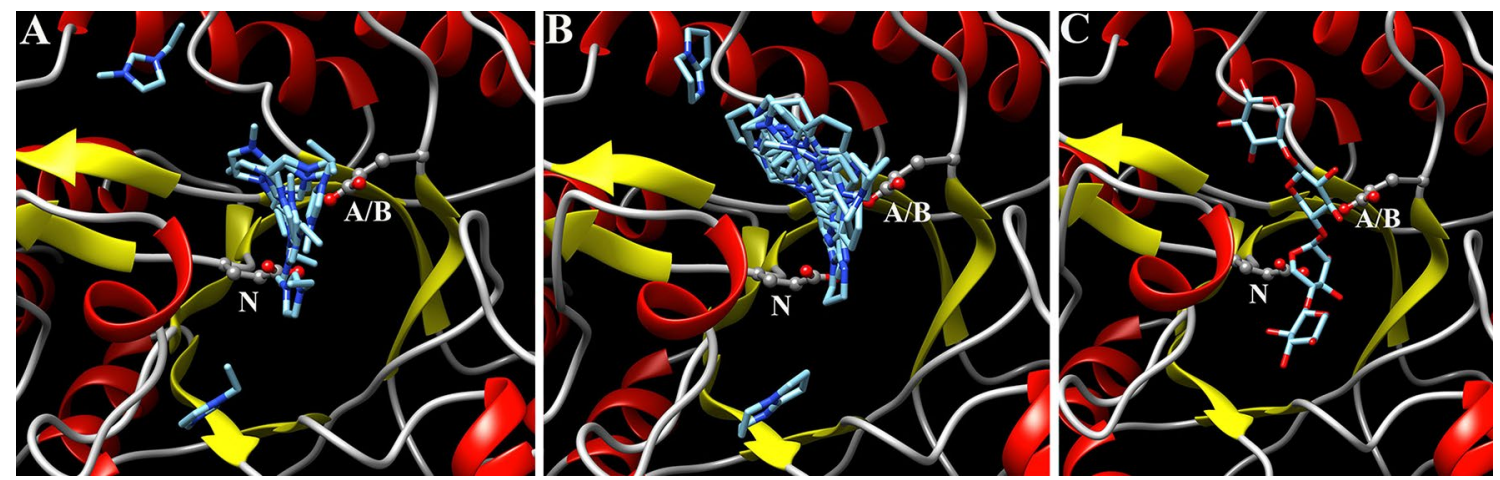

Fig. 7 Molecular docking of IL cations and xylotetraose to the structure of TmXYN10B in SwissDock. The major binding positions are shown in the enzyme active site for the $[\mathrm{EMIM}]^{+}$cations (a) and

important. Figure $7 \mathrm{c}$ shows the location of the substrate (xylotetraose) binding site in the active site. The IL cations bound to the same areas, especially those close to catalytic nucleophile and acid/base catalysts.

When xylotetraose was docked to the active site, the highest binding energy was $-10.51 \mathrm{kcal} / \mathrm{mol}$ for a structure in which the glycosidic oxygen and $\mathrm{C} 1$ of a xylose ring were close to an acid/base and nucleophile, respectively.

\section{Discussion}

Hydrophilic biomass-dissolving ILs usually have harmful effects on enzymes. The thermostability and halophilicity of proteins appear to protect against such effects (Pottkämper et al. 2009; Zhang et al. 2011; Chawachart et al. 2014). Thermostability also seems to protect against structural unfolding by ILs (Chawachart et al. 2014). Both high halophilicity and thermophilicity are properties of TmXYN10B. Furthermore, factors other than high stability are also needed for elevated activity in ILs (Li et al. 2013; Chawachart et al. 2014). One such factor is tolerance to competitive inhibition caused by IL molecules. The present study indicates that $T$. maritima xylanase is highly tolerant to both enzyme inactivation and competitive inhibition of enzyme activity by ILs.

The temperature-dependent activity assays revealed a likely effect of [EMIM]OAc on the structure of TmXYN10B. [EMIM]OAc steepened the activity increase as a function of temperature as shown in Fig. 4. This was

Table 2 Ratio between activities at 85 and $80{ }^{\circ} \mathrm{C}$ in [EMIM]OAc

\begin{tabular}{lllll}
\hline [EMIM]OAc & $0 \%$ & $15 \%$ & $25 \%$ & $35 \%$ \\
\hline $85 / 80{ }^{\circ} \mathrm{C}$ & 1.27 & 1.25 & 1.55 & 2.16 \\
\hline
\end{tabular}

The values are based on activities in Fig. 4
$[\mathrm{DBNH}]^{+}$cations $(\mathbf{b})$. The highest energy binding position of xylotetraose detected by SwissDock is shown in (c). The side chains of acid/base (A/B) and nucleophile $(\mathrm{N})$ catalytic amino acids are shown

particularly clear in the comparison of the ratio of activities at 85 and $80{ }^{\circ} \mathrm{C}$, which were much higher in 25 and $35 \%$ [EMIM]OAc than without IL or in $15 \%$ IL (Table 2). Accordingly, the Arrhenius activation increased with increasing IL concentration (Supplemental Data Fig. S3) This behaviour indicates that the TmXYN10B is more rigid in 25 and $35 \%$ [EMIM]OAc, thus requiring higher amount of thermal energy for the enzyme functioning. The increase of viscosity in the reaction solution by [EMIM]OAc was probably not the reason for this effect, as was reported elsewhere that viscosity increases first in above $40 \%$ [EMIM] OAc concentration (Quijada-Maldonado et al. 2012).

While T. aurantiacus GH10 xylanase lost about $50 \%$ of its activity at $60{ }^{\circ} \mathrm{C}$ in $25 \%$ [EMIM]OAc (Chawachart et al. 2014), TmXYN10B lost only $15 \%$ of its activity at $90{ }^{\circ} \mathrm{C}$ in $25 \%$ [EMIM]OAc (30-min standard assays). Furthermore, as compared to the disulphide bridge mutant of D. thermophilum GH11 xylanase ( $\mathrm{Li}$ et al. 2013), TmXYN10B also showed exceptional tolerance to [EMIM] OAc. With a temperature optimum of $95{ }^{\circ} \mathrm{C}$ the disulphide mutant of $D$. thermophilum GH11 xylanase lost over $80 \%$ of its activity in $25 \%$ [EMIM] OAc at $75{ }^{\circ} \mathrm{C}$ during $30 \mathrm{~min}$ of incubation, whereas TmXYN10B retained about $70 \%$ of its activity at $75{ }^{\circ} \mathrm{C}$ during $24 \mathrm{~h}$ of incubation in $25 \%$ [EMIM]OAc. Volvariella volvacea xylanase E2 was highly tolerant at the enzyme's optimum temperature (not reported in the study) to [EMIM]OAc showing $14 \%$ inactivation in 12-h assay (with pNP-xylose) (Thomas et al. 2011). However, the Volvariella volvacea enzymes have their optimum temperatures at $50-60{ }^{\circ} \mathrm{C}$ range ( $\mathrm{Li}$ et al. 2005; Zheng et al. 2013). These comparisons show that TmXYN10B has unparalleled activity at temperatures close to boiling point in a biomass-dissolving ionic liquid, [EMIM]OAc.

We previously studied the effect of a high temperature on the behaviour and kinetic parameters of extremophilic xylanases ( $\mathrm{Li}$ et al. 2015). In D. thermophilum GH11 xylanase, which has an apparent temperature optimum at $90^{\circ} \mathrm{C}$, the $K_{\mathrm{m}}$ 
value increased 5-fold in response to a shift in temperature from 90 to $100{ }^{\circ} \mathrm{C}$. In contrast, with the disulphide mutant (temperature optimum at $95{ }^{\circ} \mathrm{C}$ ), the $K_{\mathrm{m}}$ increased only 2-fold. In the present study, the $K_{\mathrm{m}}$ of TmXYN10B increased only 1.7 -fold from 90 to $100{ }^{\circ} \mathrm{C}$. These results show that at boiling point the substrate is binding well in those xylanases that have their temperature optimum at $95-100{ }^{\circ} \mathrm{C}$.

Previous research showed that [EMIM]OAc increased the $K_{\mathrm{m}}$ of xylanases, with a 9.5 -fold increase in the $K_{\mathrm{m}}$ of D. thermophilum GH11 xylanase in $15 \%$ [EMIM]OAc and a 3.5-fold increase in the $K_{\mathrm{m}}$ of Thermoascus aurantiacus GH10 xylanase (Li et al. 2013; Chawachart et al. 2014). An increase in the $K_{\mathrm{m}}$ that is accompanied by only minor effects on the $V_{\max }$ indicates competitive inhibition. GH10 xylanase showed lower competitive inhibition than GH11 xylanase (Chawachart et al. 2014). For TmXYN10B, the increase in the $K_{\mathrm{m}}$ in $15 \%$ [EMIM]OAc was minimal at 90-100 ${ }^{\circ} \mathrm{C}$ (2.0-fold and 1.1-fold, respectively) and absent at $70{ }^{\circ} \mathrm{C}$ (Table 1). These results show that the competitive inhibition is very low in TmXYN10B. However, $V_{\max }$ decreased approximately 2-fold by $15 \%$ [EMIM]OAc showing activity inhibition by some other mechanism, e.g. by a rigidifying effect of ILs on TmXYN10B. Monosaccharides and oligosaccharides are known to inhibit cellulases, which can be a significant problem in the hydrolysis of lignocellulose (Collins et al. 2005). A study of extremophilic xylanase reported weaker binding of short sugar compounds at higher temperatures ( $\mathrm{Li}$ et al. 2015). Therefore, when highly thermophilic xylanase enzymes are needed for biocatalytic processes under extreme conditions having also multiple inhibiting factors in the reaction mixture, the T. maritima GH10 xylanase appears to be a promising enzyme (Jia et al. 2012). TmXYN10B is able to resist the combined effect of more than one highly denaturing factor. The internal mobility of the proteins increases and degree of hydrogen bonding decreases with increasing temperature, and hydrogen bonds in the protein are replaced by hydrogen bonds to water (Cooper 2000). Hydrophilic ionic liquids also break hydrogen bonds and behave as surfactants denaturing enzymes (Zhao 2010).

A previous study reported that [EMIM]OAc showed stronger competition inhibition of GH11 than GH10 xylanases and that this was reflected in a larger binding area for $[\mathrm{EMIM}]^{+}$cations in the active site of the GH10 xylanase, as detected by molecular docking (Chawachart et al. 2014). In the present study, molecular docking of the IL cations and xylotetraose showed that the IL cations occupied (probably transiently) the same positions as the substrate (Fig. 7). As shown by the results of the molecular docking analysis, while the $[\mathrm{DBNH}]^{+}$cation docked to 17 different cluster positions in the active site, the $[\mathrm{EMIM}]^{+}$cation docked to only 10 cluster positions. This may indicate that the slightly larger bicyclic structure of $[\mathrm{DBNH}]^{+}$cations binds and fills the active site in a transient manner better than smaller monocyclic $[\mathrm{EMIM}]^{+}$cations. Therefore, the inhibition of the enzyme is likely to be stronger, as was seen in the present experimental studies. The highest binding energy for the $[\mathrm{EMIM}]^{+}$cations was $-7.8 \mathrm{kcal} / \mathrm{mol}$ in T. aurantiacus XYN10A ( $-6.8 \mathrm{kcal} / \mathrm{mol}$ in TmXYN10B), whereas the binding energy for good xylotetraose positioning was $-8.9 \mathrm{kcal} / \mathrm{mol}$ in T. aurantiacus (Chawachart et al. 2014). The higher binding energy for xylotetraose in the $T$. maritima enzyme $(-10.5 \mathrm{kcal} / \mathrm{mol})$ and possibly also the lower binding of the $[\mathrm{EMIM}]^{+}$cations may explain why TmXYN10B was more tolerant to ILs than the T. aurantiacus enzyme. As the substrate has higher binding affinity in TmXYN10B, it is more efficient than in the T. aurantiacus enzyme at replacing the IL molecules from the active site.

Comparing the results obtained using the three ILs, the higher activity of TmXYN10B in [EMIM]OAc than [EMIM] DMP in short assays (30 min) confirmed the influence of anions (acetate vs dimethylphosphate) on the enzyme's activity, although the difference was quite small. However, the activity order was different in long incubations (22 h), with [EMIM] DMP being best tolerated. This finding was likely due to dimethylphosphate being less denaturing than acetate. The comparison of the two ILs with acetate as the anion showed that $[\mathrm{DBNH}]^{+}$cations had a much more inactivating effect than $[\mathrm{EMIM}]^{+}$cations in long incubations. $[\mathrm{DBNH}]^{+}$cations also resulted in lower activity in short assays at higher IL concentrations. In conclusion, among the ILs tested, [EMIM] DMP showed the most promise during long incubations with TmXYN10B at very high temperatures, such as $90^{\circ} \mathrm{C}$.

While the pretreatment of lignocellulose with ILs improves subsequent enzymatic lignocellulose hydrolysis, the use of enzymes in the presence of ILs may also offer processing advantages (Wang et al. 2011; Wahlström and Suurnäkki 2015). After the IL pretreatment, the concentration of the IL has to be relatively low due to the instability of enzymes in biomass-dissolving ILs. Therefore, when using enzymes in applications that are performed in aqueous solutions of hydrophilic ILs the T. maritima xylanase can be utilised even at $90{ }^{\circ} \mathrm{C}$ in reactions that last at least 1 day, conditions that are too extreme for most other xylanases. It was shown earlier with extremophilic Pyrococcus horikoshii endoglucanase that in the lignocellulose hydrolysis, temperatures around $100{ }^{\circ} \mathrm{C}$ offer clear processing advantages for high solids reactions when compared to reactions at $70-80{ }^{\circ} \mathrm{C}$. In this respect, the ability of TmXYN10B to function in the same temperature range even in the presence of ILs may offer a possibility for building new high temperature process designs in biocatalysis. However, as the present studies were performed with isolated xylan as a substrate, conclusions cannot be drawn yet about whether the use of this extremophilic xylanase in aqueous IL solutions at high temperatures would improve the 
treatment of lignocellulose. Nevertheless, the high stability of TmXYN10B in ILs at very high temperatures makes it possible to perform such studies in industrial conditions.

Acknowledgments This work was financially supported by the Fundamental Research Funds of the University of China (CZW15026, CZW15102), Hubei Collaborative Innovation Centre for Industrial Fermentation and the Emil Aaltonen Foundation.

Open Access This article is distributed under the terms of the Creative Commons Attribution 4.0 International License (http://creativecommons.org/licenses/by/4.0/), which permits unrestricted use, distribution, and reproduction in any medium, provided you give appropriate credit to the original author(s) and the source, provide a link to the Creative Commons license, and indicate if changes were made.

\section{References}

Anbarasan S, Jänis J, Paloheimo M, Laitaoja M, Vuolanto M, Karimäki J, Vainiotalo P, Leisola M, Turunen O (2010) Effect of $\mathrm{pH}$, glycosylation and additional domains on the thermostability of family 10 xylanase of Thermopolyspora flexuosa. Appl Environ Microbiol 76:356-360

Andrade CM, Aguiar WB, Antranikian G (2001) Physiological aspects involved in production of xylanolytic enzymes by deepsea hyperthermophilic archaeon Pyrodictium abyssi. Appl Biochem Biotechnol 91-93:655-669

Bhalla A, Bansal N, Kumar S, Bischoff KM, Sani RK (2013) Improved lignocellulose conversion to biofuels with thermophilic bacteria and thermostable enzymes. Bioresour Technol 128:751-759

Canakci S, Cevher Z, Inan K, Tokgoz M, Bahar F, Kacagan M, Sal FA, Belduz AO (2012) Cloning, purification and characterization of an alkali-stable endoxylanase from thermophilic Geobacillus sp. 71. World J Microbiol Biotechnol 28:1981-1988

Chawachart N, Anbarasan S, Turunen S, Li H, Khanongnuch C, Hummel M, Sixta H, Granstrom T, Lumyong S, Turunen O (2014) Thermal behaviour and tolerance to ionic liquid [EMIM]OAc in GH10 xylanase from Thermoascus aurantiacus SL16W. Extremophiles 18:1023-1034

Collins T, Gerday C, Feller G (2005) Xylanases, xylanase families and extremophilic xylanases. FEMS Microbiol Rev 29:3-23

Cooper A (2000) Heat capacity of hydrogen-bonded networks: an alternative view of protein folding thermodynamics. Biophys Chem 85:25-39

Dumon C, Varvak A, Wall MA, Flint JE, Lewis RJ, Lakey JH, Morland C, Luginbühl P, Healey S, Todaro T, DeSantis G, Sun M, Parra-Gessert L, Tan X, Weiner DP, Gilbert HJ (2008) Engineering hyperthermostability into a GH11 xylanase is mediated by subtle changes to protein structure. J Biol Chem 283:22557-22564

Hämäläinen J, Granström T, Mollerup F, Wang Y, Xiong H, Turunen O (2015) Effect of enzymatic high temperature prehydrolysis on the subsequent cellulose hydrolysis of steam-pretreated spruce in high solids concentration. J Chem Technol Biotechnol. doi: $10.1002 /$ jctb. 4777

Ihsanawati Kumasaka T, Kaneko T, Morokuma C, Yatsunami R, Sato T, Nakamura S, Tanaka N (2005) Structural basis of the substrate subsite and the highly thermal stability of xylanase 10B from Thermotoga maritima MSB8. Proteins 61:999-1009

Jaeger V, Pfaendtner J (2013) Structure, dynamics and activity of xylanase solvated in binary mixtures of ionic liquid and water. ACS Chem Biol 117:2662-2670
Jaeger V, Burney P, Pfaendtner J (2015) Comparison of three ionic liquid-tolerant cellulases by molecular dynamics. Biophys $\mathrm{J}$ 108:880-892

Jänis J, Rouvinen J, Leisola M, Turunen O, Vainiotalo P (2001) Thermostability of endo-1,4- $\beta$-xylanase II from Trichoderma reesei studied by electrospray ionization Fourier-transform ion cyclotron resonance MS, hydrogen/deuterium-exchange reactions and dynamic light scattering. Biochem J 356:453-460

Jänis J, Turunen O, Leisola M, Derrick P, Rouvinen J, Vainiotalo P (2004) Characterization of mutant xylanases using Fourier transform ion cyclotron resonance mass spectrometry: stabilizing contributions of disulfide bridges and N-terminal extensions. Biochemistry 43:9556-9566

Jia H, Fan G, Yan Q, Liu Y, Yan Y, Jiang Z (2012) High-level expression of a hyperthermostable Thermotoga maritima xylanase in Pichia pastoris by codon optimization. J Mol Catal B-Enzym 78:72-77

Kumar V, Marin-Navarro J, Shukla P (2016) Thermostable microbial xylanases for pulp and paper industries: trends, applications and further perspectives. World J Microbiol Biotechnol $32: 34$

Li X, Pei J, Wu G, Shao W (2005) Expression, purification and characterization of a recombinant beta-glucosidase from Volvariella Volvacea. Biotechnol Lett 27:1369-1373

Li H, Kankaanpää A, Xiong H, Hummel M, Sixta H, Ojamo H, Turunen O (2013) Thermostabilization of extremophilic Dictyoglomus thermophilum $\mathrm{GH} 11$ xylanase by an N-terminal disulfide bridge and the effect of ionic liquid [EMIM]OAc on the enzymatic performance. Enzyme Microb Technol 53:414-419

Li H, Voutilainen S, Ojamo H, Turunen O (2015) The extremostability of Dictyoglomus thermophilum GH11 xylanase and its stabilized mutant. Enzyme Microb Technol 70:66-71

Malgas S, van Dyk JS, Pletschke BI (2015) A review of the enzymatic hydrolysis of mannans and synergistic interactions between $\beta$-mannanase, $\beta$-mannosidase and $\alpha$-galactosidase. World $\mathrm{J}$ Microbiol Biotechnol 31:1167-1175

Palackal N, Brennan Y, Callen WN, Dupree P, Frey G, Goubet F, Hazlewood GP, Healey S, Kang YE, Kretz KA, Lee E, Tan X, Tomlinson GL, Verruto J, Wong VW, Mathur EJ, Short JM, Robertson DE, Steer BA (2004) An evolutionary route to xylanase process fitness. Protein Sci 13:494-503

Pottkämper J, Barthen P, Ilmberger N, Schwaneberg U, Schenk A, Schulte M, Ignatiev N, Streit WR (2009) Applying metagenomics for the identification of bacterial cellulases that are stable in ionic liquids. Green Chem 11:957-965

Quijada-Maldonado E, van der Boogaart S, Lijbers JH, Meindersma GW, de Haan AB (2012) Experimental densities, dynamic viscosities and surface tensions of the ionic liquids series 1-ethyl3-methylimidazolium acetate and dicyanamide and their binary and ternary mixtures with water and ethanol at $T=(298.15-$ 343.15 K). J Chem Thermodyn 51:51-58

Reeves RA, Gibbs MD, Morris DD, Griffiths KR, Saul DJ, Bergquist PL (2000) Sequencing and expression of additional xylanase genes from the hyperthermophile Thermotoga maritima FjSS3B.1. Appl Environ Microbiol 66:1532-1537

Shrivastava S, Shukla P, Deepalakshmi PD, Mukhopadhyay K (2013) Characterization, cloning and functional expression of novel xylanase from Thermomyces lanuginosus SS-8 isolated from self-heating plant wreckage material. World J Microbiol Biotechnol 29:2407-2415

Song L, Tsang A, Sylvestre M (2015) Engineering a thermostable fungal GH10 xylanase, importance of N-terminal amino acids. Biotechnol Bioeng 112:1081-1091

Thomas MF, Li LL, Handley-Pendleton JM, van der Lelie D, Dunn JJ, Wishart JF (2011) Enzyme activity in dialkyl phosphate ionic liquids. Bioresour Technol 102:11200-11203 
Vancov T, Alston A-S, Brown T, McIntosh S (2012) Use of ionic liquids in converting lignocellulosic material to biofuels. Renew Energ 45:1-6

Vieille C, Zeikus GJ (2001) Hyperthermophilic enzymes: sources, uses, and molecular mechanisms for thermostability. Microbiol Mol Biol Rev 65:1-43

Wahlström RM, Suurnäkki A (2015) Enzymatic hydrolysis of lignocellulosic polysaccharides in the presence of ionic liquids. Green Chem 17:694

Wang Y, Radosevich M, Hayes D, Labbe N (2011) Compatible ionic liquid cellulases system for hydrolysis of lignocellulosic biomass. Biotechnol Bioeng 108:1042-1048

Wang Y, Fu Z, Huang H, Zhang H, Yao B, Xiong H, Turunen O (2012) Improved thermal performance of Thermomyces lanuginosus $\mathrm{GH}-11$ xylanase by engineering of an $\mathrm{N}$-terminal disulfide bridge. Bioresour Technol 112:275-279

Winterhalter C, Liebl W (1995) Two extremely thermostable xylanases of the hyperthermophilic bacterium Thermotoga maritima MSB8. Appl Environ Microbiol 61:1810-1815

Xiong H, Fenel F, Leisola M, Turunen O (2004) Engineering the thermostability of Trichoderma reesei endo- $\beta-1,4$-xylanase II by combination of disulphide bridges. Extremophiles 8:393-400
Xiong H, Qi SH, Xu Y, Miao L, Qian P-Y (2009) Antibiotic and antifouling compound production by the marine-derived fungus $\mathrm{Cla}$ dosporium sp. F14. J Hydro-environ Res 2:264-270

Yeoman CJ, Han Y, Dodd D, Schroeder CM, Mackie RI, Cann IK (2010) Thermostable enzymes as biocatalysts in the biofuel industry. Adv Appl Microbiol 70:1-55

Zhang T, Datta S, Eichler J, Ivanova N, Axen SD, Kerfeld CA, Chen F, Kyrpides N, Hugenholtz P, Cheng J-F, Sale KL, Simmons B, Rubin E (2011) Identification of a haloalkaliphilic and thermostable cellulase with improved ionic liquid tolerance. Green Chem 13:2083-2090

Zhao H (2010) Methods for stabilizing and activating enzymes in ionic liquids-a review. J Chem Tech Biotech 85:891-907

Zheng F, Huang J, Yin Y, Ding S (2013) A novel neutral xylanase with high SDS resistance from Volvariella volvacea: characterization and its synergistic hydrolysis of wheat bran with acetyl xylan esterase. J Ind Microbiol Biotechnol 40:1083-1093 